\title{
BIOLOGY OF THE CANCER CELL
}

\author{
Teodora Petrova ${ }^{1}$, Simeon Simeonov ${ }^{2}$, Denis Solovev ${ }^{3}$ \\ ${ }^{1}$ Assist. Prof. Ph.D., Georgi Benkovski Air Force Academy, Dolna Mitropoliya, Bulgaria \\ teodorapetrova33@abv.bg \\ 2Ph.D, University Hospital Kaneff - Rousse, Bulgaria, sansiood@abv.bg \\ ${ }^{3}$ Associate Professor, Ph.D., Far Eastern Federal University (FEFU), Vladivostok, Russian \\ Federation, solovev.db@dvfu.ru
}

\begin{abstract}
Our organism is a collection of a big number of cells, each of them an organism in its own being and which lives its own complicated life but is constantly interacting with all the other cells from this collection by adequately responding to signals from them and, in its turn, send signals. Thanks to this complex social behavior of each cell from the millions and trillions of cells helping each other and also that every cell executes its functions and has a certain location in the organism for doing so, it reproduces only when necessary and finally the cells unite with each other in the making of the multicellular organism. Despite this, cells with altered social behavior appear in the organism: these cells, to one or another degree, remain "deaf" to the signals from other cells of the organism. These 'deaf' cells reproduce regardless of the signals sent by other cells and pervade into territory occupied by other tissues. These changes in separate cells are inheritable: the 'anti-social' behavior of these cells could be transferred in cell division to the daughter cells, this process repeating infinitely many times. In the last years, the study of the process of transformation of normal cells in cancerous ones has led to even more intriguing and unexpected result: in normal cells has been found a system for interaction with certain proteins named 'system for guarding the genes'. This system protects the cells and the organism from mutations in the gene. A key role plays a protein called $p 53$.
\end{abstract}

Keywords: tumors, $p 53$ protein, thrombocyte growth factor, carcinogenic mutations.

\section{INTRODUCTION}

\subsection{The Antisocial Cells}

Our organism is a collection of a big number of cells, each of them an organism in its own being and which lives its own complicated life but is constantly interacting with all the other cells from this collection by adequately responding to signals from them and, in its turn, send signals. Thanks to this complex social behavior of each cell from the millions and trillions of cells helping each other and also that every cell executes its functions and has a certain location in the organism for doing so, it reproduces only when necessary and finally the cells unite with each other in the making of the multicellular organism. Despite this, cells with altered social behavior appear in the organism: these cells, to one or another degree, remain "deaf" to the signals from other cells of the organism. These 'deaf' cells reproduce regardless of the signals sent by other cells and pervade into territory occupied by other tissues. These changes in separate cells are inheritable: the 'anti-social' behavior of these cells could be transferred in cell division to the daughter cells, this process repeating infinitely many times. Such hereditary changes in individual cells in the organism is the result of a disturbances or mutations in their DNA, which encodes the structure of proteins in these cells. In these cells, only the parts of the DNA, which encode the protein responsible for receiving and sending 
signals from other cells mutate. From only one mutated cells, as a result of its uncontrollable division, a whole new colony is formed which is also known as a branch. All benign and malignant tumors are colonies consisting from such mutated cells. That is, all cells with antisocial behavior due to mutation in the corresponding gene are the basis for all oncologic diseases. The study of the nature of such changes is of a great importance not only for the practical medicine, but also for the theoretical biology. Thanks to the studies of mutated cells in the last years, we have gained knowledge about the nature of processes, which are responsible for the social behavior of normal cells and the molecular nature of the reactions in a cell in response to the outer signals. As it commonly happens in field of biology, the study helps to clarify the nature of the problem, which aggravates the nature of corresponding normal processes.

\subsection{The Cell Receives Signals Carried by Molecules and Responds to Them}

Signals, send from some cells to the others, are special molecules, which are distributed in the intercellular matter - if the cells are in the organism, the blood, the tissue fluid and if the cells are transplanted, those molecules are in the recipient's matter. These floating molecules can attach form the outer side of other molecules - receptors, which are located in the cells membrane and can alter their state, which activates the receptor. The inner part of the activated receptor, which is in the cells cytoplasm under the membrane, on its side, activates a mediator molecule, this molecule activates the next one until, in the end of the chain, an effector molecule is being activated. The effector molecule triggers a process, which changes the overall state of the cell, i.e. triggers the process related to cell growth and preparation for cell division. In the organism, there is a constant production of molecules, which carry a specific signal from one type of cells to another. The typical signal-carrying molecules in the organism are the hormones. For example, the cells from the anterior lobe of the hypophysis (Pituitary gland) secrete a thyroid-stimulating hormone, which activates the sensitive to this hormone specific receptors of the thyroid cells. Another example is when an organ is damaged - the wound is flown with blood in which certain types of cells - mainly thrombocytes, release a specific protein - Platelet-derived growth factors (PDGF). The fibroblast cells have PDGF receptors, which cells cover the connective tissue of the wound. When the PDFG is activated, fibroblast cells migrate to the wound and start to divide. In this way, connective tissue is being form followed by stop of accumulation of PDGF in the place of the wound and thus the stimulated multiplication of fibroblast cells ends. As it can be noted from the examples above, the division of cell in to types - one that secrete signal molecules and one that have receptors for those molecules, is the base for specific and time- and space-restricted reactions of those molecules.

The multitude of signal molecules (hormones, growth factors, etc.) defines the big diversity of interactions between cells in the organism. One of the mechanism for creating cancer cells is mutation, which leads to generation signal molecules and division of cell, which have receptors for these molecules, assuming that the signal triggers mitogenesis. For example, a mutated fibroblast begins to produce PDGF. These cells start to divide without external stimulation, they stimulate themselves and their own production of PDGF, which leads to the formation of a cancer. Tumor branches can also occur due to the mutation of genes, which encode the proteins in the signal-receptor-mediator-effector chain. When one of these genes mutate and the structure of the corresponding protein is disrupted in such a way that the protein remains constantly active, without being activated by the preceding proteins, the cells receives false signal to begin division, it starts to grow and divide without external signal molecule (the native signal). Such division of mutated cells is ceaseless and uncontrollable, that is, the cells form a tumor branch. Such mutated genes are called oncogenes and their predecessors are normal genes, which encode the proteins take part in receiving and transmitting signal - proto-oncogenes.

The systems receiving the signals can control other forms of activities in the cells, i.e. they can cause cell movement and its shift to a new place. For example, in the wound, PDGF, from thrombocytes in blood, which binds to the receptors of fibroblasts, can cause chemotaxis, that is, the direct migration of fibroblast in the wound. In this reaction, the obvious effectors are the molecules of the cytoskeleton - proteins such as actin, which is activated through the chain mediator molecule. The assembly of such molecules in special fibers emerge protrusion with temporary pseudopods on the cell's surface, and with the help of these pseudopods, the cell can migrate. The tumor cells are falsely activated by the same molecules of mutated protein - a product of oncogenes, which leads to a pathogenic mobility, which can be one of the reasons for the movement of cancer cells in neighboring tissue (invasion) or other organs (metastases).

The study of the genetic mechanism of cancer development has led to the deciphering the complex system in the cell which is responsible for receiving outer signals, which control the division and mobility of this cell. Today, tens of proto-oncogenes, which encode the molecular signals, receptors, mediators and effectors, have been found. 


\section{CANCER CELLS PROVIDE THEIR NUTRITION BY INDUCING VASCULAR GROWTH}

Cancer cells cease to react to normal signal molecules and instead, most of them start to produce and release special signal molecules and growth factors themselves. These are mainly proteins, which cause the growth of blood vessels, the so-called angiogenic factors. Cancer cells alike all other cells in the organism need nutrients and oxygen to sustain their living. Normal cells receive these through the capillary system, which is spread through all tissues. Cancer cells are constantly dividing and their number increases, the blood supply to cancer cells should constantly increase, contrary - the growth of the tumor will cease and the cancer cells will start to die due to starvation and lack of oxygen. This, however, is usually not observed since cancer cells release various angiogenic proteins in the adjacent tissues, i.e. the vascular endothelial growth factor, which is a protein, the receptors to which are found in the membranes of endothelial cells, which cover the inner wall of capillaries. Under the impact of these and other signal molecules, capillary cells begin to divide and to form new capillaries. These capillaries spread in the cancer node and provide its cells with nutrients and oxygen. The secretion of the antiogenic factor and the stimulation of vascular growth have place in the normal processes during the development of organs in the embryo or during the regeneration of organs after being damaged. The cancer cells gain the ability to use this normal reaction for, let us say, 'criminal' aims in supplying their, harmful for the organism, multiplication.

\section{P53 FUNCTIONS AND ITS IMPORTANCE IN CANCER DEVELOPMENT}

In the late years of examination of the transformation of healthy cells into cancerous ones has led to significant and unexpected results: it has been found that, in healthy cells, there is a system, which interacts with various proteins, which can be named as 'the guardian of the genome'. This system protects the cells and the organism as a whole against mutation in the genome. The main role is this system is played by a protein called $p 53$.

The protein $p 53$ was found in 1979 by L. Crawford, A. Levine, D. Lane and L. Old and it was given its name based on its molecular weight (53 kilodaltons) (Chumakov, 2007, P. 1399-1421).

The increased interest towards p53 is mainly because of its crucial role in the defence against cancer - a problem that highly concerns our society. The discovery of the many mechanisms of functioning of $p 53$ goes in parallel to the study of the fundamental mechanisms for recognition and passing of signals in cells, reparation of the genome, the regulation of cell division and its death, the coordination of metabolic processes and the regulation of the interaction between cells. Surprisingly, the function of $p 53$ appears to be related to all of the described processes, thus a communication on various levels is being maintained between the cells which results in a coherent regulatory network. One of the functions of $p 53$ is to control the state of the molecular DNA. The protein $p 53$ not only receive signals for increasing the threshold values of some molecular processes, but also provides an adequate response to those values. When a signal carrying information about diversion from the normal processes and presence of damage is generated in the genetic apparatus, $p 53$ is activated which leads to an acceleration of the repairing processes or to a halt is the cell cycle and if under high stress levels - to apoptosis. In the last case, the protein prevents the division of potentially oncogenic cells. The role of $p 53$ in the organism can be compared with the role of the conductor in an orchestra - it controls the execution of the evolutional program, which is a sum of schemes for cellular behavior in different circumstances (Vogelstein, Sur, 2010b; Ninov, Atanasov, 2019b, pp. 101-108; Terziev, Bogdanova, Kanev, Georgiev, Simeonov, 2019i, pp. 391-397; Zheltukhin, Chumakov, 2010c, 1692-1721).

In executing its control function $p 53$ is not a sole player, which is needed for running one or another processes: indeed, its activity is exhibited only if there is a deviation from the norm. Its biological role is to guarantee the stability of the genome and the genetic homogeneity in the whole organism. Unsurprisingly, the $p 53$ gene is often metaphorically referred as the 'the guardian of the genome' (Freed-Pastor, 2012, P.1268-1286; Petrova, 2019c, pp. 346-353; Stoev, Zaharieva, and Mutkov, 2019e, pp 454-457).

When the $p 53$ protein is incorrectly encoded in the gene (TP53), in $50 \%$ of the cases an oncological disease develops since the abnormal functioning of this protein makes it possible for a cell division even in case of damaged DNA. If the genes in normal cells are damaged by, let us say, $\mathrm{X}$-rays or ultraviolet rays and if those rays have caused minor tears in the DNA, then in the cell, by still unknown mechanism, the amount of $p 53$ protein drastically rises. $p 53$ guards the DNA and 'supervises' the cell cycle process. On condition that abnormalities in the growth cycle and, above all, in the DNA replication are present, $p 53$ activates the $p 21$ gene, which, on its side, binds to the cell division-stimulating protein (cdk2) to terminate the cell cycle. Under the impact of $p 53$ the cell switches over to repairing the damaged DNA. Consequently, special enzymes start repairing the tears in DNA. If, after a certain period, the normal structure of the DNA is restored and the tears 
- repaired, the amount of $p 53$ in the cell decreases to its normal levels, the cell growth is resumed and the cell restarts its program for division preparation. On the contrary, if the damage in the gene entirety proves to be significant and cannot be repaired in a reasonable period, the $p 53$ protein initialize another chain reaction, which leads to the so-called programed death or apoptosis. Apoptosis is a process, which consists of a series of destructive changes in the nucleus, mitochondria and other main components and results in cell death. The apoptosis reaction in normal development works as a way for removing cells, which have become unnecessary. For example, apoptosis of the cells of a tadpole's tail leads to the disappearance of this tale and the transformation of a tadpole into a frog. The apoptosis initialized by $p 53$ in damaged cells causes the death of those cells and further relieves the tissues of the cells with damaged gene (Fig.1) (Lane, Cheok, Lain, 2010a; Petrova, Petrov, 2018a, pp.213-228; Terziev, Petkova - Georgieva, 2019g, pp.515-524).

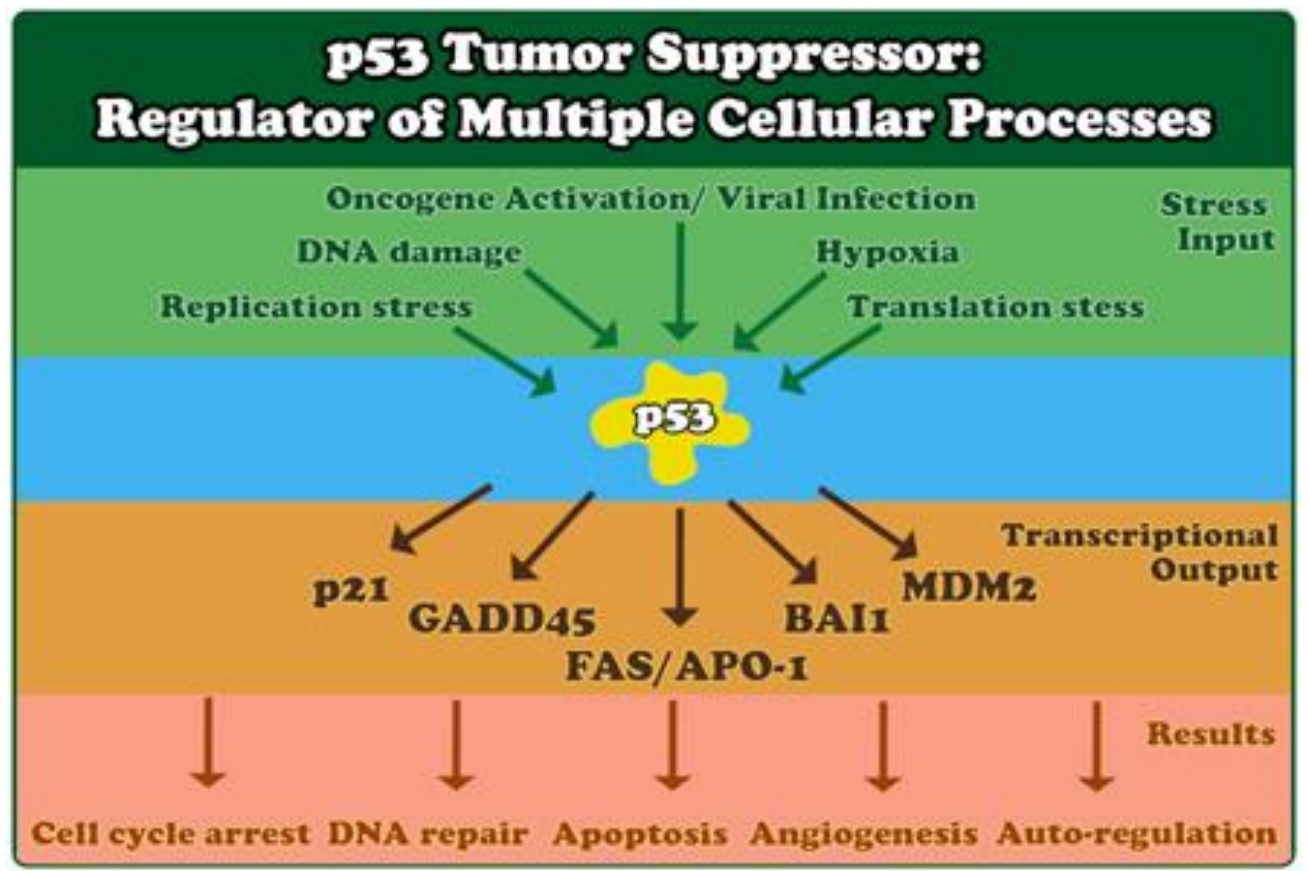

Fig.1. p53 - regulator of cell processes.

In a certain sense, $p 53$ acts as a guardian which watches for any deviations in the growth. In doing its job, $p 53$ regulates the expression of hundreds of genes. If a damaged gene is passed to the daughter cells, it can have a serious aftermath for the tissues, especially if this is a damaged region in the DNA, where the tumorsuppressing gene is located, and its transformation in an oncogene can cause unpredictable tumor development. The apoptosis of the damaged cell, apparently, ends this risk. This defensive role of $p 53$ restates the data about a rare hereditary disorder named Li Fraumeni Syndrome (LFS) (George, 2011; Liu, Xu, 2011a; Petrova, Petrov, 2019d, pp. 29-40; Terziev, Petkova - Georgieva, 2019h, pp.525-533). People, which are subject to this syndrome, have damaged (mutated) tumor suppressing gene - TP53 and therefore the produced $p 53$ is also damaged. These people have no apparent malfunctions, so they grow and develop normally, but at a relatively young age (under the age of 40) they develop malignant tumors. People with LHS are extremely susceptible to developing multiple cancers (predominantly soft tissue sarcoma, osteosarcoma, breast cancer, brain and CNS tumors, and adrenal gland tumors) due to the impossibility of the organism to tackle the affected cells, which, eventually, become immortalized. Hence, about $50 \%$ of the individuals with LFS develop cancer by the age of 40 and up to $90 \%$ chance by the age of 60 with many of those individuals having two or more over their lifetime. A brief scheme of the mechanism of cancer development is presented below: 


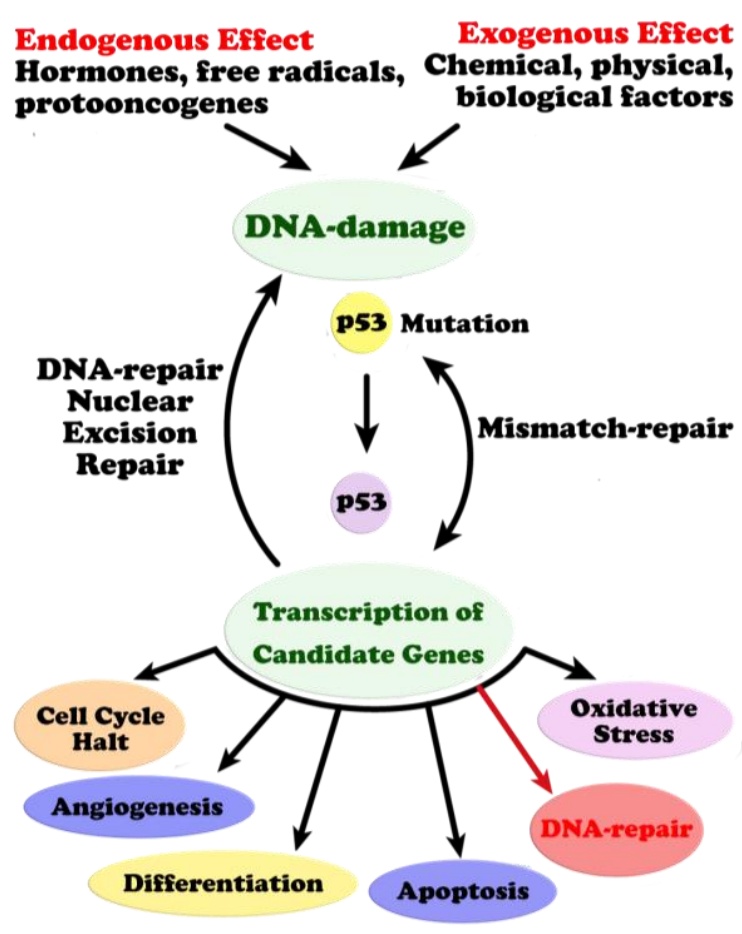

Fig. 2. Basic mechanism of cancer development

\section{Oxidative stress and the $p 53$ gene}

The oxidative stress is caused by the lack of a balance between the formation of free radicals and the ability of the body to counteract or neutralize their harmful impact with the help of antioxidants. In response to low levels of oxidative stress, $p 53$ acts as an antioxidant and eliminates the oxidative stress, while when the latter is of a great level, $p 53$ acts as a pro-oxidant and additionally increases the stress level, which leads to cell death. This function of $p 53$ prevents the transfer of damaged DNA to the daughter cells and maintains the genome stability.

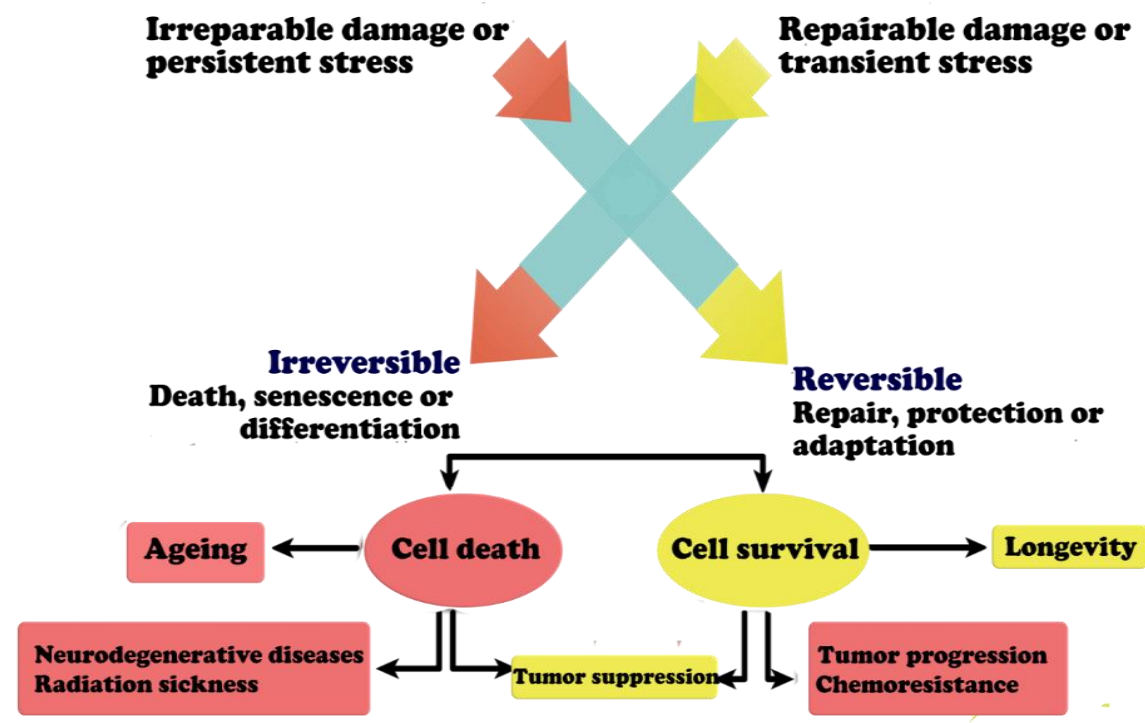

Fig. 3. Tumor suppression.

It has been found out that the significance of $p 53$ is not only in the prevention of negative impacts on the genome. It also modulates the metabolism, increases the activity of processes responsible for the antioxidant protection and detoxification, effects the intensity of protein synthesis, regulates the recovery processes of cells, which cannot divide and stimulates the reproductive functions of the body. This functions of $p 53$ are aimed to prevent diseases such as atherosclerosis, various metabolic disorders, neurodegenerative pathologies and premature aging of the body. Recent studies shows the negative role of 
$p 53$ in the development of some pathologies. Chronical stress and local inflammation processes constantly stimulate the expression of TP53 gene and the protein leads to the apoptosis of cells and the release of active forms of oxygen. Therefore, the excessive work of $p 53$ results in worsening the disease (Muller, Vousden, 2013, P. 2-8; Stoev, Zaharieva, Borodzhieva, 2019f, pp 458-461; Atanasov, 2019a).

$p 53$ is significant for examining the pathogenesis of diseases and has big therapeutical potential. Now it is still unclear how to employ the enormous amount of information about this protein. However, one might predict that the knowledge of $p 53$, gathered up until now, will eventually be used for cancer prevention and treatment (Govedarski, et al. 2013; Genadiev et al. 2015; Kirilova - Doneva et al. 2015a; Sopotenski, Petrova, Chervenyakov, 2011; Kirilova-Doneva, Kamusheva, Petrova, Sopotenski, 2016; Tsonkova, 2018b; Tsonkova, 2014).

\section{CONCLUSION}

Usually, the cancer development is the result of not only one mutation, but is a consequence of a whole series of mutations, which lead to the appearance of new cancer cells, and more and more oncogenes and the deactivation of anti-oncogenes. Each mutation creates new and modified branches, which take the place of other less modified branches. Because of the pathologic character of cancers (fast growth rate, ability to invade and metastasize), they increase in number and become more noticeable - making them harmful to the organism. Since every mutation is a random process, the development time and the specific character of the changes are unpredictable - they vary with each tumor. Biological methods have allowed finding more than a dozen of mutations in oncogenes and anti-oncogenes in a single cell of human cancer. When, however, the cancer growth goes along with fewer mutations, there, obviously, would be fewer changes in the organism and the cancer development might go unnoticed by either the patient or the doctor. Thus, the evolution of normal cells in highly malignant branches can continue for few decades, which is the main reason for the raise in the number of malignant cancers with the age (Terziev, Petkova- Georgieva, 2019j-p).

\section{REFERENCE LIST}

Chumakov P.M. (2007). Versatile functions of protein in multicellular organisms. Biochemistry (Mosc), 72 (2007), P. $1399-1421$.

Freed-Pastor W.A. (2012). Prives C. Mutant p53: one name, many proteins. Genes Dev., 26 (2012), P.1268 1286.

George P. (2011). p53 How crucial is its role in cancer? Int J Curr Pharm Res 3: 19 -25.

Lane D.P., Cheok C.F., Lain S. (2010a). p53-based cancer therapy. Cold Spring Harb Perspect Biol 2 (9): a001222.

Muller P.A., Vousden K.H. (2014). Mutant in cancer: new functions and therapeutic opportunities. Cancer Cell, 25 (2014), P. 304-317.

Muller P.A., Vousden K.H. (2013). p53 mutations in cancer. Nat. Cell Biol., 15 (2013), P. 2-8.

Vogelstein B., Sur S. (2010b). Prives C.: the most frequently altered gene in human cancers. Nature Education. 2010; 3:6.

Liu D, Xu Y. (2011a). Oxidative Stress, and Aging. Antioxidants \& Redox Signaling. 2011;15(6):1669-1678

Atanasov, Plamen. (2019a). "Variation of the Organisational Reputation in A 4.0 Environment - Fighting for Trust under the Conditions of Communicational Abundance". Postmodernism Problems 9 (2), 248-69.

Ninov, M., Atanasov P. (2019b). Content Analysis as a Way of Identifying Hybrid Threats in the Media Content, International Journal on Information Technologies and Security, No. 3 (vol. 11), 2019, pp. 101-108.

Petrova T, (2019c). Modeling Of Temperature Distribution In Biotissues, Proceedings of SOCIOINT 20196th International Conference on Education, Social Sciences and Humanities, 24-26 June 2019Istanbul, Turkey, pp. 346-353, ISBN 978-605-82433-6-1

Petrova T, Petrov Zh., (2018a). Modelling the Distribution of Lasers in Biological Tissues, Int $\mathrm{J}$ Bioautomation, 22 (3), 213-228, doi: 10.7546/ijba.2018.22.3.213-228 
Petrova T, Petrov Zh., (2019d). Peculiarities in the Distribution of Temperature under the Influence of a Laser Beam in a Multilayered Medium, Int J Bioautomation, 23 (1), 29-40, doi: 10.7546/ijba.2019.23.1.29-40

Stoev I., Zaharieva S., and Mutkov V. (2019e). Evaluation of Gross Errors in Measured Temperature with an Electronic System for Management of Residential Energy Systems, International Scientific Conference 27th Telecommunications Forum, ISBN: 978-1-7281-4789-5, pp 454-457

Stoev I., Zaharieva S., and Borodzhieva A. (2019f). An Approach for Assessment of the Synchronization Between Digital Temperature Sensors, International Scientific Conference 27th Telecommunications Forum, ISBN: 978-1-7281-4789-5, pp 458-461

Terziev, V., Petkova - Georgieva, S. (2019g). The performance measurment system key indicators and the determinants impact on the level of decentralization using as an example a subdivisional unit from the Bulgarian social health and care experience. // Proceedings of SOCIOINT 2019-6th International Conference on Education, Social Sciences and Humanities 24-26 June 2019- Istanbul, Turkey, International Organization Center of Academic Research, Istanbul, Turkey, 2019, pp. 515-524, ISBN: 978-605-82433-6-1 DOI: 10.2139/ssrn.3411542

Terziev, V., Petkova - Georgieva, S. (2019h). A research study of nonlinearity experiencing in the rate of current account deficit to the Bulgarian health and care national product. // Proceedings of SOCIOINT 2019- 6th International Conference on Education, Social Sciences and Humanities 24-26 June 2019Istanbul, Turkey, International Organization Center of Academic Research, Istanbul, Turkey, 2019, pp. 525-533, ISBN: 978-605-82433-6-1. DOI: 10.2139/ssrn.3411558

Terziev, V., Bogdanova, M., Kanev, D., Georgiev, M, Simeonov, S. (2019i). The social assistance system in Bulgaria. // Proceedings of ADVED 2019 - 5th International Conference on Advances in Education and Social Sciences, 21-23 October 2019, International Organization Center of Academic Research, Istanbul, Turkey, 2019, pp. 391-397, ISBN: 978-605-82433-7-8.

Zheltukhin A.O., Chumakov P.M. (2010c). Constitutive and induced functions of the p53 gene. Biochemistry (Mosc.) 75, 1692-1721.

Govedarski, V., Kratunkov, P., Petrov, I., Genadiev, S., Zahariev, T., Nachev, G. (2013). Embolizatsii na anomalni sadove pri tumorni formatsii. // Hirurgiya, 69, 2013, №2, s. 44-47; ISSN 0450-2167 45924 (Говедарски, В., Кратунков, П., Петров, И., Генадиев, С., Захариев, Т., Начев, Г. Емболизации на аномални съдове при туморни формации. // Хирургия, 69, 2013, №2, с. 44-47; ISSN 0450-2167 45924).

Genadiev, S., Govedarski, V., Petrov, I., Zahariev, T., Nachev, G. (2015). Hirurgichni metodi za lechenie na varikoznata bolest. // Balgarska gradna, sardechna i sadova hirurgiya, 2015, №1, s. 34-39; ISSN 1313-9339 51956 (Генадиев, С., Говедарски, В., Петров, И., Захариев, Т., Начев, Г. Хирургични методи за лечение на варикозната болест. // Българска гръдна, сърдечна и съдова хирургия, 2015, №1, c. 34-39; ISSN 1313-9339 51956).

Kirilova - Doneva, M., D. Pashkouleva, V. Kavardzhikov, S. Sopotensky, G. Petrova, N. Gerasimov. (2015a). Evaluation of mechanical alternations of expanded hernia mesh - Series on Biomechanics, vol. 29, No 2-3, 2015.

Sopotenski, S., Petrova, G., Chervenyakov, A. (2011). Achalasia: surgical and social aspects of diagnostics and therapy. Meditsinski Pregled / Medical Review 2011 Vol. 47 No. 1 pp. 19-29.

Kirilova-Doneva, M., Kamusheva, M., Petrova, G., Sopotenski, S. (2016). Comparison of costs for elective versus emergency hernia repair and its reimbursement in Bulgaria, EESJ, 2016, v.2, 9(13), 43-49.

Tsonkova, Eva. (2018b). Nablyudenie varhu efekta na preparata Bimbi apetito pri lechenie na 17g.patsientka s nachalni simptomi na Anorexia Nervosa. Sp. Pediatriya, tom LVIII, 2018, str.46-48, ISSN 0479-7876 (Цонкова, Ева. Наблюдение върху ефекта на препарата Бимби апетито при лечение на 17г.пациентка с начални симптоми на Anorexia Nervosa. Сп. Педиатрия, том LVIII, 2018, стр.4648, ISSN 0479-7876).

Tsonkova, Eva. (2014). Retrospektivno 10-godishno prouchvane varhu babrechno - kamennata bolest sred hospitaliziranite patsienti v Detsko otdelenie na MBAL Ruse AD. // Nauchni trudove na Rusenski universitet 2014, tom 53, seriya 8.3., str.256-259, ISSN 1311-3321 (print), ISSN 2535-1028 (CDROM), ISSN 2603-4123 (on-line) (Цонкова, Ева. Ретроспективно 10-годишно проучване върху бъбречно - каменната болест сред хоспитализираните пациенти в Детско отделение на МБАЛ Русе АД. // Научни трудове на Русенски университет 2014, том 53, серия 8.3., стр.256-259, ISSN 
1311-3321 (print), ISSN 2535-1028 (CD-ROM) , ISSN 2603-4123 (on-line)).

Terziev, V., Petkova- Georgieva, S. (2019j). The Bulgarian health care system practical research on the usefulness of the performance measurement system. // Proceedings of ADVED 2019 - 5th International Conference on Advances in Education and Social Sciences, 21-23 October 2019, International Organization Center of Academic Research, Istanbul, Turkey, 2019, pp. 369 - 375, ISBN: 978-605-82433-7-8.

Terziev, V., Petkova- Georgieva, S. (2019k). The pesticides toxic impact on the human health condition and the ecosystem. // Proceedings of ADVED 2019 - 5th International Conference on Advances in Education and Social Sciences, 21-23 October 2019, International Organization Center of Academic Research, Istanbul, Turkey, 2019, pp. 376 - 382, ISBN: 978-605-82433-7-8.

Terziev, V., Petkova- Georgieva, S. (2019l). Human health problems and the classification of the most toxic pesticides. // Proceedings of ADVED 2019 - 5th International Conference on Advances in Education and Social Sciences, 21-23 October 2019, International Organization Center of Academic Research, Istanbul, Turkey, 2019, pp. 383 - 390, ISBN: 978-605-82433-7-8.

Terziev, V., Petkova- Georgieva, S. (2019m). Organo-phosphonate, organo-halogenated, cyanides and arsenic toxic impact on the human health care condition. // Proceedings of ADVED 2019 - 5th International Conference on Advances in Education and Social Sciences, 21-23 October 2019, International Organization Center of Academic Research, Istanbul, Turkey, 2019, pp. 426 - 431, ISBN: 978-605-82433-7-8.

Terziev, V., Petkova- Georgieva, S. (2019n). Toxic chemical compounds detection for the society social health care prevention. // Proceedings of ADVED 2019 - 5th International Conference on Advances in Education and Social Sciences, 21-23 October 2019, International Organization Center of Academic Research, Istanbul, Turkey, 2019, pp. 432 - 442, ISBN: 978-605-82433-7-8.

Terziev, V., Petkova- Georgieva, S. (2019o). Human health prevention by detection and quantification of toxic chemical compounds. // Proceedings of ADVED 2019 - 5th International Conference on Advances in Education and Social Sciences, 21-23 October 2019, International Organization Center of Academic Research, Istanbul, Turkey, 2019, pp. 443 - 449, ISBN: 978-605-82433-7-8.

Terziev, V., Petkova- Georgieva, S. (2019p). The level of decentralization impact on the Bulgarian social health care competitiveness. // Proceedings of ADVED 2019 - 5th International Conference on Advances in Education and Social Sciences, 21-23 October 2019, International Organization Center of Academic Research, Istanbul, Turkey, 2019, pp. 361 - 368, ISBN: 978-605-82433-7-8. 